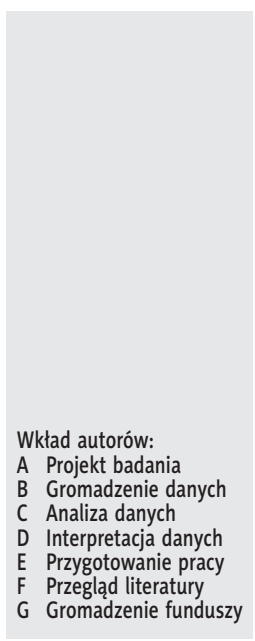

\title{
Hospitalizacje psychologiczne pacjentów z szumami usznymi - subiektywna ocena dokonywana przez uczestników
}

\section{Psychological hospitalization of patients suffering from tinnitus - subjective evaluation of participants}

\author{
Matgorzata Fludra ${ }^{A B C D E}$, Karina Karendys-ŁuszCz ${ }^{\text {BDF }}$, Izabela Sarnicka ${ }^{\mathrm{BDEF}}$ \\ Instytut Fizjologii i Patologii Słuchu, Światowe Centrum Słuchu, Warszawa/Kajetany
}

Streszczenie

Wstęp: Celem hospitalizacji psychologicznych prowadzonych w Instytucie Fizjologii i Patologii Słuchu, opartych na założeniach terapii poznawczo-behawioralnej, jest ułatwienie pacjentom adaptacji do dolegliwości, jaką są szumy uszne. Zadaniem działań rehabilitacyjnych jest kształtowanie takich reakcji na szumy uszne w obszarach percepcji, uwagi, emocji i zachowania, które wpłyną na zmianę odczuwania ich dokuczliwości i poprawę funkcjonowania pacjenta w życiu codziennym.

Cel: Celem pracy jest przedstawienie rezultatów subiektywnej oceny rehabilitacji psychologicznych oraz ich wpływu na poznawcze i emocjonalne reakcje związane z odczuwaniem szumów usznych, dokonanej przez pacjentów uczestniczących w tych hospitalizacjach. Materiał i metody: Na hospitalizację kierowano pacjentów zdiagnozowanych audiologicznie, poinformowanych o zasadach terapii TRT. Osobami badanymi było 152 pacjentów (śr. wiek 55,9 lat) uczestniczących w tygodniowej, stacjonarnej rehabilitacji psychologicznej. Badani wypełniali ankietę dotyczącą przebytej terapii stworzoną na potrzeby niniejszego badania. Oceny dokonywano bezpośrednio po zakończonej hospitalizacji rehabilitacyjnej.

Wyniki i wnioski: Otrzymane wyniki pokazują, że hospitalizacje psychologiczne są, z punktu widzenia pacjenta, istotnym elementem terapii szumów usznych.

Słowa kluczowe: szumy uszne • rehabilitacja • terapia poznawczo-behawioralna

Abstract

Introduction: The aim of the psychological hospitalization in the Institute of Physiology and Pathology of Hearing is to facilitate patients' adaptation to tinnitus. It is based on cognitive behavioral therapy. The therapy is designed to change patient's reactions to tinnitus in different fields such as perception, attention, emotions and behaviour. As an effect the therapy is to make tinnitus less troublesome and improve patient's functioning in everyday life.

Aim: The aim of this study was to show the result of both subiective assesment of psychological rehabilitation made by its attendands and the influence of the rehabilitaton on cognitive functioning of patients and their behavioral reactions connected with their perception of tinnitus.

Material and method: The research group consisted of 152 audiologically diagnosed patients (average age of 55.9 years). They were informed about the rules of Tinnitus Retraining Therapy (TRT). They all attended one week psychological hospitalization conducted at the Institute. At the end of their stay patients filled oud an evaluation questionnaire developed for this study.

Results and conclusions: The results of the assessment show that patiens percieve psychological hospitalization as a crucial part of tinnitus therapy.

Key words: tinnitus • rehabilitation • cognitive behavioral therapy

Adres autora: Małgorzata Fludra, Światowe Centrum Słuchu, ul. Mokra 17, Kajetany, 05-830 Nadarzyn, e-mail: m.fludra@ifps.org.pl 


\section{Wstęp}

Szumy uszne są dość powszechnie występującą dolegliwością. Badania przeprowadzone w 1998 i 1999 roku w Instytucie Fizjologii i Patologii Słuchu pokazały, że szumy uszne trwające ponad 5 minut odczuwa $20,1 \%$ polskiej populacji powyżej osiemnastego roku życia, natomiast stałych szumów doświadcza 4,8\% Polaków [1]. Praktyka kliniczna i liczne badania pokazują, że stopień dokuczliwości szumów usznych może być różny - dla niektórych pacjentów szumy nie stanowią żadnego problemu, innym przeszkadzają wyłącznie w ciszy, części natomiast znacznie pogarszają codzienne funkcjonowanie i samopoczucie. Na przykład badania Stouffera i Tylera [2] pokazują, że 60\% pacjentów, u których wystąpiły szumy uszne, w początkowej fazie ich występowania odczuwa lęk o swoje zdrowie i życie. Obniżenie nastroju mierzone Inwentarzem BDI w badaniu Zielińskiej-Bliźniewskiej i wsp. [3] obserwowane jest u 45\% badanych osób, przy czym u większości występują łagodne zaburzenia nastroju. Jednak najczęściej zgłaszanym przez pacjentów z szumami usznymi problemem są zaburzenia snu. Według badań Fludry i wsp. [4] występują one u $64 \%$ pacjentów. Tinnitus może utrudniać wypoczynek oraz wpływać na pogorszenie zdolności koncentracji przejawiające się trudnościami z utrzymaniem i podzielnością uwagi oraz wydłużonym czasem reakcji [5-6].

Jak pokazują badania, większość pacjentów (80-90\%) habituuje szumy uszne [7], jednak dla części z nich wystąpienie szumów jest sytuacją kryzysową przekraczającą adaptacyjne możliwości radzenia sobie. Ważne jest zatem, aby tym osobom, dla których tinnitus stanowi poważny problem, stworzyć szanse na poprawę jakości życia. W Instytucie Fizjologii i Patologii Słuchu od 2004 roku prowadzone są hospitalizacje psychologiczne dla pacjentów, którzy mają problemy z radzeniem sobie z dolegliwością, jaką są szumy uszne, zarówno w aspekcie emocjonalnym, poznawczym, jak i behawioralnym. Jest to autorski program stworzony przez psychologów i lekarzy Instytutu, oparty na założeniach terapii poznawczo- behawioralnej (ang. Cognitive Behaviour Therapy, CBT). Na terapię kierowani są pacjenci, którzy zostali wcześniej poddani diagnozie audiologicznej, poinformowani o zasadach terapii TRT (ang. Tinnitus Retraining Therapy) i skonsultowani przez psychologa. Hospitalizacja odbywa się w formie tygodniowej, grupowej terapii stacjonarnej prowadzonej przez psychologów. Jej celem jest rozwinięcie przez pacjentów w niej uczestniczących umiejętności redukowania wpływu szumów na samopoczucie i jakość życia, wykształcenie korzystnych dla pacjenta sposobów reagowania na szumy uszne w sferze postrzegania, uwagi i procesów emocjonalnych oraz rozwinięcie umiejętności radzenia sobie ze stresem. Hospitalizacja taka składa się z trzech rodzajów zajęć: psychologicznych, relaksacyjnych i ruchowych.

\section{Zajęcia psychologiczne}

Zajęcia te opierają się na założeniach terapii poznawczo-behawioralnej stosowanej, z pozytywnymi wynikami potwierdzonymi badaniami [8], m.in. w leczeniu zaburzeń lękowych i depresyjnych, w pomaganiu pacjentom w lepszym radzeniu sobie $\mathrm{z}$ chorobami somatycznymi, m.in. chronicznym bólem, cukrzycą, bólami głowy i problemami sercowo- naczyniowymi. Terapia CBT skoncentrowana jest na „tu i teraz”, czyli na konkretnym problemie destabilizującym pacjenta. Zakłada, że człowiek aktywnie konstruuje własną rzeczywistość, nadając znaczenie bodźcom napływającym $z$ otoczenia, a myśli, emocje, zachowania i reakcje fizjologiczne są elementami jednego systemu i wzajemnie na siebie oddziałują. Zatem np. negatywne myślenie związane z szumami usznymi wpływa na reakcje emocjonalne oraz nadmierne skupienie uwagi na szumie - jest to tzw. mechanizm błędnego koła, który leży u podstaw nasilania się dokuczliwości szumów usznych. Podczas zajęć psychologicznych pacjenci uświadamiają sobie swoje negatywne myśli i przekonania w stosunku do szumów usznych i ich wpływ na emocje i zachowania, a następnie modyfikują je na bardziej konstruktywne. $W$ trakcie tych zajęć pacjenci otrzymują informacje dotyczące szumów usznych i mechanizmów słyszenia, weryfikując je ze swoimi dotychczasowymi przekonaniami. Mają także możliwość przeprowadzania eksperymentów behawioralnych. Uczą się również technik pomocnych w kontrolowaniu uwagi. Zajęcia w plenerze, podczas których pacjenci mają za zadanie zapamiętać jak najwięcej zewnętrznych dźwięków, czy ćwiczenie w parach, często oceniane przez pacjentów jako przełomowe dla ich myślenia o tinnitusie, w którym to jedna osoba ma zawiązane oczy, a druga jest jej przewodnikiem, są przykładami eksperymentów behawioralnych, w jakich biorą udział pacjenci. Dzięki nim uczestnicy mogą doświadczyć, w jaki sposób można kierować swoją uwagą, jak szybko można przerzucić ją na inne bodźce, tracąc przy tym świadomość odczuwania szumów usznych. Tak więc stosowane techniki behawioralne i poznawcze mają pomóc $\mathrm{w}$ wypracowaniu nowych strategii radzenia sobie z szumami usznymi i przez to ułatwić proces adaptacji do dolegliwości.

\section{Zajęcia relaksacyjne}

Odwołując się do wcześniej omawianych założeń terapii poznawczo-behawioralnej, zajęcia te mają na celu redukcję napięcia emocjonalnego poprzez zmniejszenie napięcia mięśniowego. Podstawową techniką wykorzystywaną podczas tych zajęć jest oddychanie przeponowe, które stabilizuje procesy fizjologiczne, uspokaja, rozluźnia. Jest stosunkowo proste do nauczenia się przez pacjentów i łatwe do wykorzystywania w codziennym funkcjonowaniu. Leży też u podstaw innych technik relaksacyjnych, tj. również stosowanej podczas hospitalizacji relaksacji progresywnej Jacobsona oraz wizualizacji [9]. Progresywna relaksacja mięśni redukuje stres, lęk, poprawia nastrój. Badania wskazują, że jest skutecznie wykorzystywana we wspomaganiu leczenia zaburzeń psychicznych i somatycznych [10]. Wizualizacja wykorzystuje wyobraźnię pacjenta w celu zmniejszenia napięcia, rozluźnienia mięśni, ale pomaga również ukierunkować pacjenta na określony cel w przyszłości [11]. W trakcie zajęć pacjenci mają możliwość poznania tych technik, przećwiczenia ich, czyli zebrania własnych doświadczeń związanych z ich stosowaniem. Otrzymują zatem konkretne „narzędzia”, które mogą stosować po powrocie do swojego codziennego funkcjonowania.

\section{Zajęcia ruchowe}

Zajęcia te maja na celu zachęcenie pacjentów do aktywności fizycznej w codziennym życiu. Badania pokazują, że regularny wysiłek fizyczny zmniejsza reakcję układu 


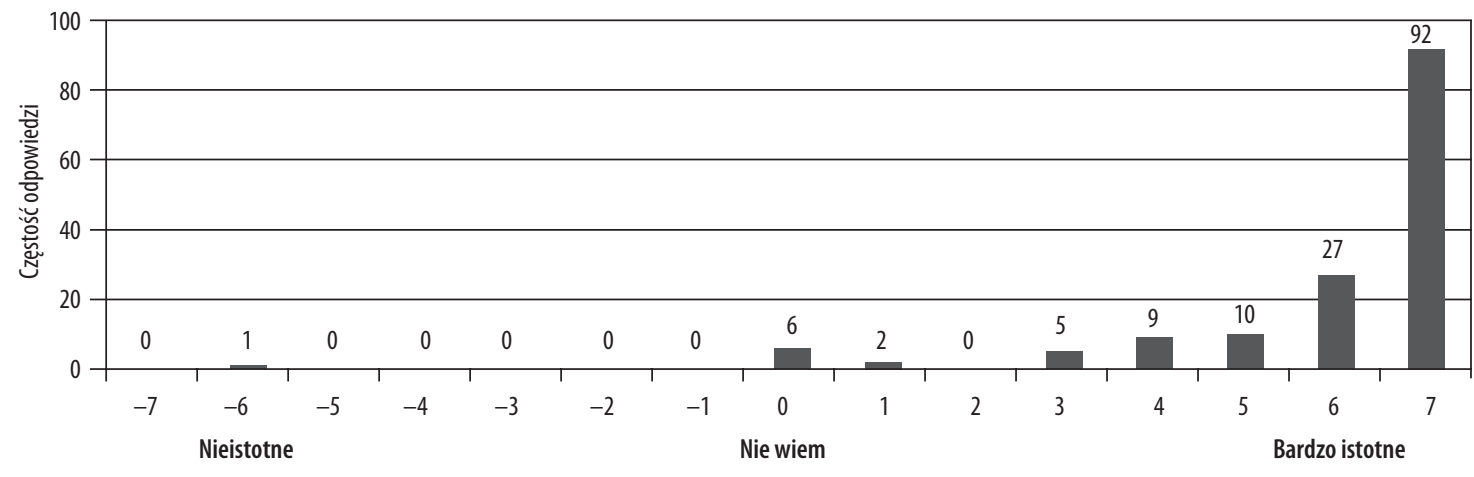

Istotność hispitalizacji

Rycina 1. Ocena istotności hospitalizacji psychologicznej w leczeniu szumów usznych - częstość odpowiedzi Figure 1. Assessment of the significance of psychological intervention - prevalence of patients responses

odpornościowego na stres [12] - w sytuacji stresowej wydzielana jest mniejsza ilość kortyzolu. Powoduje również zwiększenie wydzielania dopaminy i endorfin [13]. Przegląd badań dokonany przez Górniaka i Rybakowskiego [14] wskazuje na pozytywne znaczenie wysiłku fizycznego w leczeniu depresji, schizofrenii, zapobieganiu otępienia i zmniejszaniu zaburzeń snu. Warunkiem jest, żeby wysiłek był umiarkowany i regularny (ale nie częstszy niż 5 razy w tygodniu po $30 \mathrm{~min}$ ). Dodatkowo w przypadku pacjentów z szumami usznymi wysiłek fizyczny jest również formą ćwiczenia kontroli uwagi. Uwaga zostaje zwrócona na prawidłowe wykonywanie ćwiczeń, właściwe oddychanie, dzięki czemu zwiększa się prawdopodobieństwo zmniejszenia świadomości odczuwania szumów usznych.

\section{Cel}

Celem niniejszej pracy jest przedstawienie oceny psychologicznych hospitalizacji rehabilitacyjnych dokonanej przez pacjentów w nich uczestniczących pod kątem: ich istotności w procesie leczenia, przydatności bloków tematycznych terapii, wpływu na wiedzę na temat szumów usznych oraz na ich dokuczliwość i ogólne samopoczucie. Badanie miało na celu oprócz sprawdzenia subiektywnej oceny skuteczności terapii zebranie opinii pacjentów na temat poszczególnych bloków zajęciowych, co miałoby istotne znaczenie dla dokonania ewentualnych zmian w planie terapeutycznym.

\section{Materiał i metoda}

Badaniami objęto 152 pacjentów ze zdiagnozowanymi szumami usznymi, którzy uczestniczyli w psychologicznej hospitalizacji rehabilitacyjnej w Międzynarodowym Centrum Rehabilitacji w Łebie. Kobiety stanowiły 70\% badanych, mężczyźni - 30\%. Wiek badanych mieścił się w przedziale: od 28 do 74 lat, średnia wieku 55,9 lat $(S D=9,7)$. Badani wypełniali ankietę dotyczącą przebytej terapii, stworzoną na potrzeby niniejszego badania, zawierającą dwanaście pytań. Oceny dokonywano na wizualnej skali analogowej, bezpośrednio po zakończonej hospitalizacji rehabilitacyjnej. Pytania dotyczyły: oceny istotności hospitalizacji rehabilitacyjnych w procesie leczenia szumów usznych (skala od -7 do 7), przydatności poszczególnych bloków zajęciowych (np. Na ile przydatne w terapii szumów usznych

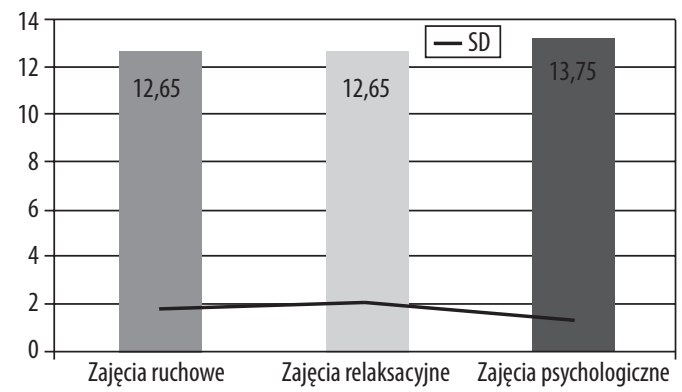

Rycina 2. Ocena przydatności bloków tematycznych terapii - średnie i odchylenia standardowe

Figure 2. Assessment of usefulness of different topics in therapy - average and standard deviation

są, według Pana/Pani, zajęcia z psychologiem (proszę zaznaczyć na skali)? Wizualna skala analogowa od 0 do 14 , gdzie 0 oznacza „w ogóle nie są przydatne| do 14 - „są bardzo przydatne"), wpływu hospitalizacji na dokuczliwość tinnitusa (np. Czy po hospitalizacji rehabilitacyjnej zmieniła się dokuczliwość szumów usznych (proszę zaznaczyć na skali)? Wizualna skala analogowa od -7 do 7 , gdzie -7 oznacza „zdecydowanie się zwiększyła”, 0 oznacza „bez zmian”, a 7 - „zdecydowanie zmniejszyła się”), odczuwane rozdrażnienie (skala od -7 do 7), ogólne samopoczucie (skala od -7 do 7) oraz wiedzę na temat szumów usznych (skala od 0 do14).

\section{Wyniki}

Biorąc pod uwagę częstość odpowiedzi, zdecydowana większość pacjentów (78\%) uważa, że hospitalizacje rehabilitacyjne są istotne w procesie leczenia szumów usznych. Jedynie $4 \%$ nie ma zdania, a jako nieistotnie uważa je $0,7 \%$ pacjentów biorących w nich udział (rycina 1).

Wszystkie trzy rodzaje zajęć zostały przez pacjentów ocenione jako bardzo przydatne w terapii szumów usznych (rycina 2). Średnia ocena zajęć psychologicznych to 13,17 $(\mathrm{SD}=1,4)$ przy maksymalnie 14 punktach. Natomiast średnia ocen dla zajęć relaksacyjnych i ruchowych to 12,65 $(\mathrm{SD}=2,1$ i $\mathrm{SD}=1,8)$. 


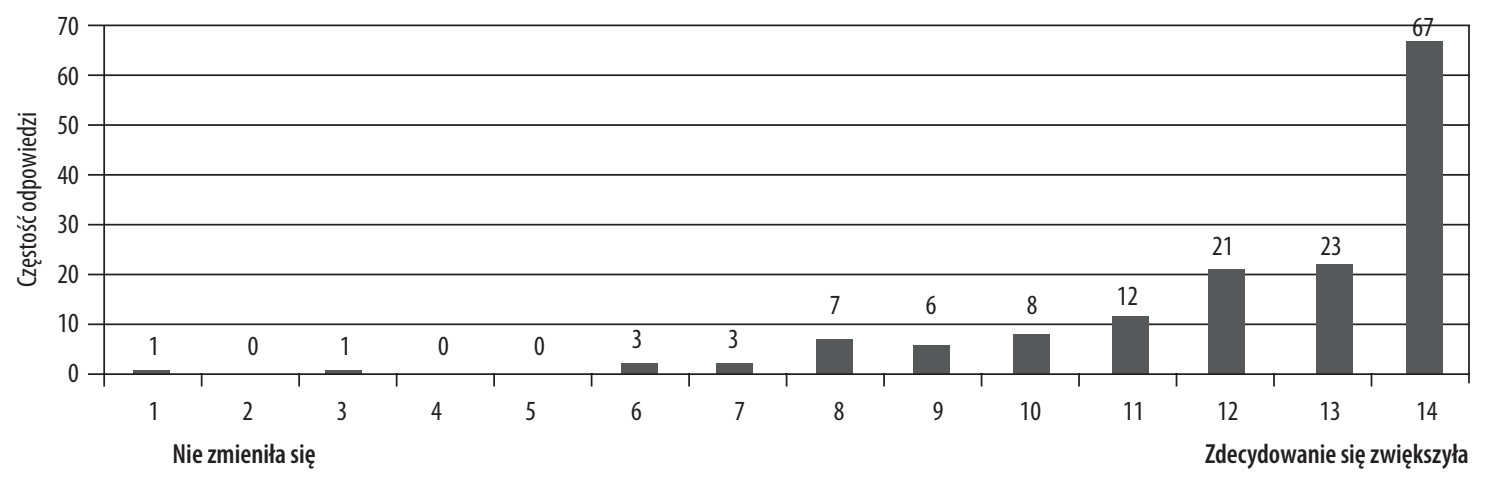

Wiedza

Rycina 3. Ocena wpływu terapii na poziom wiedzy dotyczącej szumów usznych - częstość odpowiedzi

Figure 3. Assessment of influence of psychological hospitalization on general knowledge concerning tinnitus - responce prevalence

Biorąc pod uwagę częstość odpowiedzi, $44 \%$ pacjentów zaznacza maksymalną wielkość na skali „Wiedza”, co oznacza, że ich zdaniem hospitalizacje wpłynęły zdecydowanie na zwiększenie się ich wiedzy na temat szumów usznych (rycina 3).

Według pacjentów hospitalizacje w znaczny sposób wpływają na poprawę ogólnego samopoczucia - średnia ocen 5,7 (max. 7). Najmniejszy wpływ tej formy terapii zauważono na zmniejszenie odczuwanej dokuczliwości szumów usznych ocenianej bezpośrednio po zakończeniu hospitalizacji (rycina 4).

\section{Dyskusja}

Wcześniejsze badania udowodniły pozytywny wpływ terapii poznawczo-behwioralnej na redukcję dyskomfortu związanego z odczuwaniem szumów usznych [15-18]. Kolejne badania pokazały, że dzięki połączeniu różnych form interwencji, np. treningów relaksacyjnych, terapii TRT i edukacji na temat szumów usznych, można uzyskać lepszy efekt redukcji wpływu tinnitusa na jakość życia pacjentów $[19,20]$. Omawiane w niniejszej pracy hospitalizacje psychologiczne także są połączeniem zróżnicowanych form pracy z pacjentami, ale wyróżniają się intensywnością przeprowadzanych, w stosunkowo krótkim czasie, zajęć. Tym bardziej istotna jest ocena przydatności takiej formy hospitalizacji psychologicznych w terapii szumów usznych. Pytania w ankiecie, jaką wypełniali pacjenci, odnosiły się zarówno do bezpośredniej oceny istotności hospitalizacji, ważności poszczególnych bloków tematycznych, jak i pośredniej - czyli ich wpływu na wiedzę dotyczącą dolegliwości, ogólne samopoczucie, rozdrażnienie związane z szumami, odczuwaną dokuczliwość.

Przedstawione w niniejszej pracy wyniki wskazują, że $\mathrm{z}$ punktu widzenia pacjentów w nich uczestniczących hospitalizacje psychologiczne są bardzo istotne w leczeniu szumów usznych. Wszystkie rodzaje proponowanych w trakcie hospitalizacji zajęć (psychologiczne, relaksacyjne i ruchowe) zostały przez pacjentów ocenione jako mające duże znaczenie dla terapii szumów usznych. Wynik ten oznacza, że proponowana forma terapii, mimo swojej intensywności, jest dla pacjentów atrakcyjna w swojej różnorodności i doborze zajęć.

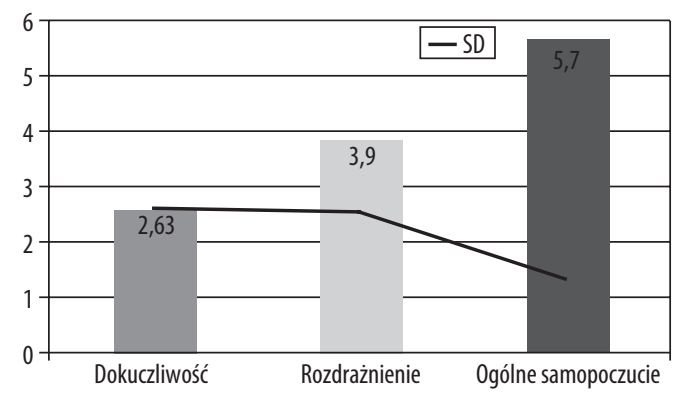

Rycina 4. Ocena wpływu hospitalizacji na ogólne samopoczucie, rozdrażnienie związane z odczuwaniem szumów i ich dokuczliwość - średnie i odchylenia standardowe

Figure 4. Assessment of an impact of psychological hospitalization on general well-being, irritation associated with tinnitus and it's annoyance - average and standard deviation

Przeprowadzone badanie pokazało również, że pacjenci pozytywnie oceniają wpływ hospitalizacji psychologicznych na radzenie sobie z szumami usznymi zarówno pod względem odczuwanego rozdrażnienia związanego z szumami usznymi, jak i ich dokuczliwości. Ta forma terapii wpływa na poszerzenie wiedzy na temat szumów usznych, a biorąc po uwagę wynikający z założeń terapii poznawczo-behawioralnej wpływ procesów poznawczych na emocje i zachowanie, może być jedną z przyczyn zmniejszenia się zarówno rozdrażnienia, jak i dokuczliwości szumów usznych. Kolejnymi czynnikami wpływającymi na uzyskane w badaniu wyniki mogą być: zmniejszenie poczucia wyjątkowości, poczucie akceptacji i wzajemnego wsparcia oraz nadzieja na poprawę funkcjonowania $z$ szumami usznymi. Czynniki te są wynikami procesu grupowego, jaki ma miejsce podczas hospitalizacji [21].

W 2004 roku została przeprowadzona wśród pacjentów uczestniczących w psychologicznych hospitalizacjach rehabilitacyjnych ankieta oceniająca ich wpływ na dokuczliwość szumów usznych - 71\% z nich stwierdziło, że ta forma terapii wpływa na jej zmniejszenie [22]. Podobny wynik uzyskano w obecnym badaniu - $67,7 \%$ pacjentów zauważyło zmniejszenie dokuczliwości tinnitusa. 
Biorąc pod uwagę otrzymane wyniki wpływu hospitalizacji na dokuczliwość, rozdrażnienie i ogólne samopoczucie, można zauważyć, że największej poprawie uległo ogólne samopoczucie pacjentów, co jest prawdopodobnie związane z nałożeniem się bezpośredniego wpływu zajęć oraz oderwania się pacjentów od codziennych obowiązków. Dokuczliwość szumów usznych w ocenie pacjentów podlega najmniejszym zmianom. Wydaje się, że właściwym byłoby sprawdzenie, jak jest rozumiana przez pacjentów „dokuczliwość”. Jak wskazuje doświadczenie kliniczne badaczy, niektórzy pacjenci rozumieją „dokuczliwość” jako „głośność” czy „intensywność” szumów usznych, czyli jako aspekt fizyczny. Ponieważ hospitalizacje nastawione są na poprawę sposobów radzenia sobie z szumami usznymi, taki sposób myślenia o „dokuczliwości” może leżeć u podstaw jej stosunkowo mniejszej zmiany. Badanie prowadzone było bezpośrednio po zakończeniu hospitalizacji, w związku z tym konieczne są dalsze badania nad skutecznością tej formy terapii. Należy sprawdzić, jaki jest ich wpływ na radzenie sobie pacjentów z szumami usznymi po powrocie do codziennych obowiązków. Wydaje się, że dokuczliwość szumów w związku z koncentracją na innych bodźcach powinna się obniżać, natomiast ogólne samopoczucie może się pogarszać ze względu na zmniejszenie czasu przeznaczonego na relaks i odpoczynek.

\section{Wnioski}

- Otrzymane wyniki pokazują, że prowadzone w Instytucie Fizjologii i Patologii Słuchu hospitalizacje psychologiczne są ważnym elementem terapii szumów usznych.

- Z punktu widzenia pacjentów proponowana forma hospitalizacji psychologicznych jest właściwie dopasowana do ich potrzeb.

- Pacjenci pozytywnie oceniają wpływ hospitalizacji na radzenie sobie z szumami usznymi w kontekście zmniejszenia dokuczliwości szumów, rozdrażnienia z nimi związanego i poprawy ogólnego samopoczucia.

- Konieczne są dalsze badania dotyczące utrzymania się w czasie efektów hospitalizacji psychologicznych.

\section{Piśmiennictwo:}

1. Fabijańska A, Rogowski M, Bartnik G, Skarżyński H. Epidemiology of tinnitus in Poland. W: Hazel J, red. Proceedings of the Sixth International Tinnitus Seminar. Cambridge UK, London: The Tinnitus and Hyperacussis Centre; 1999, s. 567-69.

2. Stouffer JL, Tyler RS. Characterization of tinnitus by tinnitus patients. J Speech Hear Disord, 1990; 55: 439-53.

3. Zielińska-Bliźniewska H, Olszewski J. Szumy uszne a depresja. Otolaryngol Pol, 2009; 63(7): 200-203.

4. Fludra M, Karendys-Łuszcz K, Rostkowska J, Sarnicka I. Zaburzenia snu wśród pacjentów z szumami usznymi. W druku.

5. Tyler RS, Baker LJ. Difficulties experienced by tinnitus sufferers. J Speech Hear Disord, 1983; 48: 150-54.

6. Andersson G, Vretblad P. Anxiety sensitivity in patients with chronic tinnitus. Scand J Behav Ther, 2000; 29(2): 57-64.

7. Rossiter S, Stevens C, Walker G. Tinnitus and its effect on working memory and attention. J Speech Lang Hear Res, 2006; 49: $150-60$.

8. Andersson G, Baguley DM, McKenna 1, McFerran DJ. Tinnitus: A multidisciplinary approach. London: Whurr; 2005.

9. Popiel A. Pragłowska E. Psychoterapia poznawczo-behawioralna - praktyka oparta na badaniach empirycznych. Psychiatria w Praktyce Klinicznej, 2009; 2(3): 146-55.

10. McCallie MS, Blum CM, Hood CJ. Progressive muscle relaxation. J Hum Behav Soc Environ, 2006; 13(3): 51-66.

11. Sławińska A. Zastosowanie progresywnej relaksacji mięśni Jacobsona w praktyce klinicznej. Psychiatria i Psychoterapia, 2016; 12(4): 3-15

12. Jakubowska-Winecka A, Włodarczyk D (red.). Psychologia w praktyce medycznej. Warszawa: Wydawnictwo Lekarskie PZWL; 2007.

13. Zschucke E, Renneberg B, Dimeo F, Wüstenberg T, Ströhle A. The stress-buffering effect of acute exercise: Evidence for HPA axis negative feedback. Psychoneuroendocrinology, 2015; 51: $414-25$.
14. Górniak M, Rybakowski J. Wpływ aktywności fizycznej na zaburzenia psychiczne. Farmakoter Psychiatr Neurol, 2015; 31(2): $113-26$.

15. Rimer J, Dwan K, Lawlor DA, Greig CA, McMurdo M, MorleyW i wsp. Exercise for depression. Cochrane Database Syst Rev, 2012; 11(7): 123-30.

16. Hesser H, Weise C, Westin VZ, Andersson G. A systematic review and meta-analysis of randomized controlled trials of cognitive behavioral therapy for tinnitus distress. Clin Psychol Rev, 2011; 31(4): 545-53.

17. Cima RF, Maes IH, Joore MA, Scheyen DJ, El Refaie A, Baguley DM i wsp. Specialised treatment based on cognitive behaviour therapy versus usual care for tinnitus: A randomised controlled trial. Lancet, 2012; 379(9830): 1951-59.

18. Cima RF, Andersson G, Schmidt CJ, Henry JA. Cognitive-behavioral treatments for tinnitus: A review of the literature. J Am Acad Audiol, 2014; 25(1): 29-61.

19. Henry JL, Wilson PH. The psychological management of chronic tinnitus: A cognitive-behavioral approach. Boston: Allyn\&Bacon; 2001.

20. Kröner-Herwig B, Frazel A, Fritsche G, Schilkowsky G, Esser G. The management of chronic tinnitus: Comparison of outpatient conitive-behavioral group training to minimal-contact intervention. J Psychosom Res, 2003; 54: 381-89.

21. Yalom I, Leszcz M. Psychoterapia grupowa. Teoria i praktyka. Kraków: Wydawnictwo Uniwersytetu Jagielońskiego; 2006.

22. Borawska B, Bartnik G, Karpiesz L, Szymańska E, Senderski A, Skarżyński H. Wstępna ocena przydatności terapii dźwiękowej u pacjentów z szumami usznymi i/lub nadwrażliwością słuchową leczonych metodą habituacji (TRT). Audiofonologia, 2004; 24: 145-53. 